\title{
The Positive Effect of Creative Movement Model on Children's Personal Skills
}

\author{
Ni Putu Sinta Dewi ${ }^{1}$, Putu Aditya Antara ${ }^{2}$, Putu Rahayu Ujianti ${ }^{3}$ \\ 1,2,3 Department of Early Childhood Education, Ganesha University of Education, Bali-Indonesia \\ *Corresponding author: putusintadewi2804@gmail.com
}

\begin{abstract}
As the importance of personal skills stimulation for children to prepare and equip children in facing various learning levels of further education is necessary, research about it is needed. This study examined the effect of creative movement model on the personal skills of early childhood. This study used a quasi-experimental approach with post-test only control group design. The population of this study was students of Group B Cluster III Kindergarten in Payangan District, Gianyar which the sample was Melati Kindergarten as an experimental group with treatment and Hindu Widya Kumara Santhi Kindergarten as a control group without treatment. Data analysis of the study was descriptive statistics and inferential statistics, by using t-test that was processed by IBM SPSS Statistics ver. 24 for Windows. The result of data interpretation in hypothesis test showed that Sig. (2-tailed) score was 0.001 which meant the significance score was smaller than $\alpha(0.001<0.05)$. According to these statements, it could be concluded that Ho was rejected and Ha was accepted. The study demonstrates that creative movement model has positive effect on children's personal skills. With this finding, parents and especially educators expected to be willing to develop various creative movement activities that can stimulate children's personal skills more optimally and sustainably. The benchmarks of children's achievement should go beyond cognitive aspects; thus, teachers need to provide stimulation for children's personal skills to develop social emotional aspect.
\end{abstract}

Keywords: model, creative movement, personal skills, early childhood

\section{Introduction}

Personal skills are part of life skills which are important to be stimulated from early childhood. World Health Organization or WHO classifies life skills into five groups, namely self-awareness or personal skills, social skill, thinking skill, academic skill, and vocational skills (Yusria, 2016). Meanwhile in the realm of early childhood, life skills are focused on personal skills.

Personal skills are the most basic skills that must be mastered by children in learning about life skills (Lazarus, 1991). In the realm of early childhood education personal skills which are observed have relation to aspects of self-awareness, initiative, and independence of children (Sriningsih, 2010). Personal skills in kindergarten are not emphasized on technical and vocational skills as secondary school level do. Personal skills are the ability of children to help themselves to survive (Smith, 2003). Based on that statement, early personal skills development can be achieved by giving special stimulation for children to help them 
recognizing themselves, interacting to environment, and getting basic skill that will be useful for their next life level.

The importance of teaching personal skills to children based on Goleman's research shows that IQ only contributes $20 \%$ to the success on someone life, while $80 \%$ is determined by other factors outside of IQ, such as life skills (Sriningsih, 2010). In this context it can be understood that the success of one's life requires personal skills which include selfawareness, independence, and initiative (Sriningsih, 2010). Personal skills are very important to be stimulated from early age, as a basic skill before introducing another life skill to children.

In general, the implementation of learning in early childhood education especially in kindergartens, personal skills are grouped into affective domain (Olivia, 2014). According to Kostelik (1999) components of children's personal skills belong to affective domain which have several elements, including self-awareness, initiative and independence. Personal skills' elements in the report and assessment of learning outcomes usually are translated into several indicators such as attitude and behavior; patience, tolerance, responsibility, never give up, play according to interest, and take the initiative to start activity (Yusria, 2016)

Nowadays, there are parents who think stimulation of personal skills are not yet needed for early childhood (Kusumaastuti, 2014). They are more focused on developing children's academic skills especially targeting and forcing the children to master certain skills at the time. For example, when children enter kindergarten, they must be able to read, write and count (Summers et al., 2008). It is similar to parents entering their children to various kinds of tutoring class that hopefully can improve children's academic skills.

Forcing the children to master certain skills can disrupt their process of growth and development. Related to the learning process in kindergarten, the learning given focuses more on reading, writing and arithmetic which is incomplete and may have a negative impact on children's development (Sollehuddin, 1997). This condition will only develop some aspects of individual skills while "turning off" the development of other skills (Yusria, 2016). This certainly becomes a paradigm that actually deviates from the concept of early childhood education because educators should prepare learning that is centered on children's interests.

In addition, most of kindergarten schools only slip material of personal skills into habitual activities that can be observed in tidying toys, performing, enthusiastic when learning in class, and wearing their own clothes (Sriningsih, 2010). Those activities can only stimulate the aspect of independence in the child's personal abilities meanwhile the aspects of self-awareness and initiative have not been maximally stimulated (Mashar, 2011). It can be 
understood that stimulation of personal skills has not been running optimally on children (Nugraha et al., 2017).

Based on interviews with school stakeholders in Cluster III Kindergarten, Payangan District, Gianyar there were children who have not been able to demonstrate good personal skills. In addition, the results of preliminary observations of 156 children of group B group III of Payangan District, from 6 indicators of children's personal skills that were observed there were 4 indicators that children were not able to do. The example of indicators was initiative to start an activity in which children was not able to start an activity independently (still waiting for a friend's direction or teacher's direction), such as going forward to the class, telling their experience, and doing their own worship activities but most of them were waiting for other friends first.

The low level of children's personal skills at the school is often caused by a lack of activities stimulation that involved children's self-awareness, initiative, and independence (Dow, 2010). Regarding the indicator of responsibility, children were not able to take responsibility for maintaining the cleanliness of their table and chair, and the neatness of their locker. Children also often did not tidy up toys when they finished using them by leaving it in messy and scattered. In terms of never giving up indicator, children often did not complete their task and quickly say "I cannot do it" even though the children were given clear instruction. For indicator of playing based on their interests, children did not show ways to express their interests optimally. This was due to the lack of activities and materials that were in accordance with the interests of each child. In addition, most of kindergarten schools in Cluster III Payangan District do not include specific criteria and result of personal skills assessment in the children's report card. Based on interview with teacher, personal skills assessment was translated directly into the social emotional and independence aspects, and it was included in the habituation assessment component. Activities that related to social emotional and independence were only packaged in habituation activities such as tidying the tables and chairs, class and self-cleaning activities, and doing tasks independently. However, it had not been able to stimulate personal skills optimally because those activities were done too often. Usually they only stimulated cooperation, patience, and independence of children. These activities were not able to stimulate self-awareness elements such as expressing themselves and interacting with others and initiative elements optimally as expected.

The success of training personal skills can not only rely on one component, the other components such as self-awareness and initiative must also be given in the same stimulation then children get the full stimulation of personal skills. For example, indicators of expressing 
themselves and coordinating body organs in the children's self-awareness component should be stimulated with activities that involve movement. The experience of movement activities can give children the freedom to cultivate their bodies, develop self-confidence, express themselves and as a container for developing children's creativity (Skoning, 2008). Freedom in managing the body and expressing themselves is indicator in self-awareness, creativity is related to initiative, and self-confidence is an indicator of independence (Laban, 1988).

Seeing those relationships, researcher tried to offer recommendations to stimulate the components of self-awareness, initiative, and independence of children with creative movement activities. Manipulative motion gives an opportunity for children to hone the coordination of motor organs with motor, motor with eyes, and maintain children's body balance (Hidayat \& Darma, 2017). In other hand, art provides an opportunity for children to be free to create and express themselves according to their imagination without any rules that increase and limit the child's self (Antara, 2015). Then by providing stimulation of creative movement, children will have more opportunities to know themselves, and can stimulate personal skills optimally.

Similar finding was also found by Antara (2018) that creative motion contributed greatly to children's social-emotional, cognitive, and physical development. This is also supported by Laban (1988) and Hawkins (2003) which stated that moving experience that took place while playing focuses on the aesthetic qualities of motion and bodily skills and lead to personal skills. The result of this study was also emphasized by Antara (2018) who found that there were differences in the spatial abilities between children who got creative games with creative motion and children who got creative games by playing roles. As the result, there was an influence of the use of creative games with creative motion and role playing on children's spatial abilities. The spatial ability of children who got creative games with creative motion was higher than the spatial ability of children who got creative games by playing roles.

Hermayanti (2015) also found that creative dancing activity could increase children's confidence which was one indicator of children's personal skills. The results of actions taken from 10 respondents. In pre-cycle, it found that average confidence of children was $26,25 \%$ and in the cycle I was 55,52\%. Then the score from pre-cycle to first cycle increased by $29.27 \%$. The percentage of next cycle was $87.05 \%$. Then from cycle I to cycle II increased by $31.53 \%$. Overall calculation from pre cycle to cycle II increased by $60.80 \%$. So, from the discussion it can be stated that creative movement model has positive effect on children's personal skills. 
Movement activities have important role for psychomotor development, cognitive abilities and affective abilities (Gallahue, 1998). In line of this theory, Yusria (2016) suggested that personal skills in early childhood entered into the affective domain which included self-awareness, initiative, and independence. Self-awareness is an ability to feel the feelings when feelings emerge (Hurlock, 1978). According to Kostelnik (1999) selfawareness is also related to physical attributes when children begin to think about what they can do, and what distinguishes themselves from others.

The term of self-awareness refers to an individual's introspective and reflective attention to their experience, or it is referred as sensitivity (Goleman, 1996). For example, self-awareness that shows negative and positive feelings such as guilt and pride (Sriningsih, 2010). In childhood, with competencies that emerge, they try to build a sense of self-control, adequacy, and pride in their achievements (Santrock, 2007). The sensitivity and self-control are related to the concept of creative movement that links elements of spatial ability and children's ability to coordinate their bodies, and express their emotions appropriately. Simply in implementing creative movement a child needs space to move according to the imagination, measures and adjusts the movement to avoid other friend's movement, arranges and coordinates his hands, eyes, and body when moving, and also creates facial expressions when making movements.

Initiative is one aspect of personal skills. Initiative is needed by children in creating creative motion. Initiative according to the Indonesian Big Dictionary (locally known as Kamus Besar Bahasa Indonesia or KBBI) is a derivative word from "initiative" which means the initial effort or action raised by someone. In practicing creative motion, children have opportunity to start the movements without waiting for direction from the teacher or from friend. The initiative is also related to creativity (Hidayat \& Darma, 2017). Freedom of creativity gives children the confidence to start something. In creative movement children are given opportunity to create creativity with their imagination and explore environment freely. Thus, it can be understood that creative motion can be a trigger for children's creativity. So, it can have a positive impact on children's initiatives.

Independence is a basic skill in personal skills. Independence is an individual's internal strength that is obtained through the process of individualization (Sugito, 2013). Autonomy or independence means well behaved and controlled (Dodge and Colker, 2002). Independence can be interpreted as an ability to think, feel, and do something alone or not dependent on others. By being independent which is taught early on, children will be helped to have confidence in wanting and deciding something for themselves (Familia, 2006). One 
important aspect of autonomy is emotional autonomy when children are able to release dependencies on their parents. Children are able balancing themselves, deciding their destiny, and controlling from others. They find the power to have own independence (Papalia, Olds, and Feldman, 2009).

Children are stimulated to be able to be independent in choosing motion object, confident in displaying motion, and never give up in arranging and displaying movements to be presented in front of the class. In addition, children are expected to not only have initiative and creativity in creating movement but also independence and self-confidence. Thus, this study aimed at examining the effect of creative movement model on children's personal skills especially on Group B Cluster III Kindergarten academic year 2019/2020 in Payangan District.

\section{Materials and Methods}

This study was conducted to examine about the effect of the creative movement model on the personal skills in early childhood especially kindergarten students. The research method used a quasi-experimental approach with post-test only control group as design (Dantes, 2012). The population of this study were group B cluster III kindergarten where Melati Kindergarten as experimental group which got treatment and Hindu Widya Kumara Santhi Kindergarten as control group without treatment.

The steps of the research were: 1) determining the sample of the population, 2) looking for preliminary data about the personal skills to identify how far the development materials of personal skills at schools on Group B Cluster III in Payangan district, 3) validating observation sheets by experts judgement, 4) conducting research which was preceded by giving instruments before the treatment to teachers, 5) giving treatment to the experimental class in the form of learning with a maximum of 12 meetings, while allowing the control class being taught with conventional learning. The final stage of experimental research was giving a post-test for both groups at the end of the study. The post-test was administered in a single meeting for each group. The result of the post-test was analyzed by descriptive statistic analysis and inferential statistics through IBM SPSS Statistics ver. 24 for Windows. To find out the quality of the personal skills variable the mean score was converted by using ideal average criteria (Mi) and ideal standard deviation (SDi) which is presented in Table 1.

Table 1. Benchmark Reference Criteria for Personal Skills

\begin{tabular}{lll}
\hline Number Value & Criteria & Letter Description \\
\hline $34,75-<40,00$ & $4=\mathrm{A}$ & Very Good/Very High \\
\hline
\end{tabular}




\begin{tabular}{lll}
\hline $25,50-<33,25$ & $3=\mathrm{B}$ & Good/High \\
$20,25-<24,75$ & $2=\mathrm{C}$ & Fair/Moderate \\
$15,75-<19,15$ & $1=\mathrm{D}$ & Poor/Low \\
$10,25-<14,75$ & $0=\mathrm{E}$ & Very Poor/Very Low \\
\hline
\end{tabular}

\section{Results and Discussion}

\section{Experiment Group Data Description}

After being treated 12 meetings, students were given a post-test to obtain personal skills data. The data analyzed in this study were the post-test data of group B children who were taught by creative movement model. Personal skills data from this group showed the highest score was 40 and the lowest score was 16.

\section{Control Group Data Description}

The data analysis in this study were obtained from the post-test result of students in control group. Personal skills data from the post-test scores in the control group showed the highest score was 30 and the lowest score was 14. The frequency distribution of the students' personal skills data on the experiment and control group is presented in Table 2.

Tabel 2. Frequency distribution of students' personal skills data on the experiment and control group

\begin{tabular}{|c|c|c|c|c|c|c|c|c|c|}
\hline \multicolumn{2}{|c|}{ Interval Class } & \multicolumn{2}{|c|}{$\mathbf{X}$} & \multicolumn{2}{|c|}{$\mathbf{F}$} & \multicolumn{2}{|c|}{ FK } & \multicolumn{2}{|c|}{$\mathbf{F x}$} \\
\hline 1 & 2 & 1 & 2 & 1 & 2 & 1 & 2 & 1 & 2 \\
\hline $16-20$ & $10-15$ & 18 & 13 & 5 & 1 & 8 & 1 & 90 & 13 \\
\hline $21-25$ & $16-20$ & 24 & 18 & 9 & 5 & 17 & 6 & 216 & 90 \\
\hline $26-30$ & $21-25$ & 26 & 23 & 4 & 8 & 21 & 14 & 104 & 184 \\
\hline $31-35$ & $26-30$ & 33 & 28 & 3 & 4 & 24 & 18 & 99 & 224 \\
\hline $36-40$ & & 38 & & 2 & & 26 & & 76 & \\
\hline & & & & 23 & 23 & & & 585 & 511 \\
\hline
\end{tabular}

$\begin{array}{ll}\text { Note : } \\ \mathrm{X} & : \text { Median } \\ \mathrm{F} & : \text { Absolute frequency } \\ \mathrm{Fx} & : \text { Absolute frequency multiplied by median } \\ \mathrm{Fk} & : \text { Cumulative frequency } \\ 1 & \text { : Experiment Class } \\ 2 & \text { : Control Class }\end{array}$

\section{Data Distribution of Normality Test}

The normality test of data distribution was done as term for conducting hypothesis testing (Sugiyono, 2009). The normality test in this study was assisted by using the IBM SPSS Statistics version 24. Summary of normality test result is presented in Table 3.

Table 3. Summary of Normality Test Result (Levene's Test) by using IBM SPSS Statistics version 24

\begin{tabular}{cccc}
\hline Group & Kolmogorov-Smirnov & Shapiro-Wilk & Remark \\
\hline Experiment & 0,198 & 0,609 & Normal \\
Control & 0,200 & 0,410 & Normal \\
\hline
\end{tabular}

The normality test in this study used the Kolmogorof Smirnov and Shapiro Wilk test (Test of Normality) which was processed by IBM SPSS version 24. The results of data above 
could be interpreted that the data distribution from the post tests of both groups had normal distribution. It could be seen from the significance scores of Kolmogorov-Smirnov and Shapiro-Wilk personal skill in the creative movement model data (experimental) which was 0.198 and 0.609 , while in control group was 0.2 and 0.410 . As the result, the significance number of both group above was greater than 0.05 . It means that the personal skills data in the experimental group and in control group were statistically insignificant; thus, the null hypothesis was accepted. As the conclusion, the sample data was proved coming from populations that were normally distributed.

\section{Homogeneity of Variance Test}

Homogeneity test in this study was processed by using IBM SPSS Statistics version 24. Homogeneity of variance test result is presented in Table 4.

Table 4. Homogeneity of Variance Test Result

\begin{tabular}{ccccc}
\hline Levene's Statistic & df1 & df2 & Sig. & Remark \\
\hline 2,314 & 1 & 44 & 0,135 & Homogeneous \\
\hline
\end{tabular}

From the homogeneity test results table above, it could be interpreted that the significance of the children's personal skills was 0.135 . The significance level was greater than 0.05. It showed sig. $>\alpha$ which means the variance in each group was equal (homogeneous). As the result, the variance of children's personal skills in each group was homogeneous.

\section{Hypothesis Testing}

Hypothesis test of research was performed by using the $\mathrm{T}$ polled variance formula which was processed with IBM SPSS Statistics version 24. The hypotheses of study can be seen below. Meanwhile hypothesis test result is presented in Table 04.

$\mathrm{H} 1: \mu 1 \mathrm{~A} 1 \neq \mu 2 \mathrm{~A} 2$ : there was a significant difference between the creative movement model towards personal skills on Group B Cluster III Kindergarten academic year 2019/2020 in Payangan District

Note:

$\mu 1 \mathrm{~A} 1=$ average score of control group

$\mu 2 \mathrm{~A} 2=$ average score of experimental group

Table 5. Hypothesis Test Result

\begin{tabular}{ccccc}
\hline $\mathbf{t}_{\text {count }}$ & df & Sig.(2-tailed) & $\mathbf{t}_{\text {tabel }}$ & Description \\
\hline 3,674 & 44 & 0,001 & 2,021 & $\begin{array}{c}\text { Ha was accepted, Ho } \\
\text { was rejected }\end{array}$ \\
\hline
\end{tabular}


Based on the table above, the data could be interpreted that the Sig. (2-tailed) score obtained 0.001 that had meaning the significance score was smaller than $\alpha(0.001<0.05)$. The score of tcount $=3.674$ while ttable $=2.021$ which meant $t_{\text {count }}>t_{\text {table. }}$. According to two statements, it could be taken a decision which Ho was rejected and Ha was accepted. The description of the decision above showed that there was a significant difference in the personal skills between children who taught with creative movement model and those who taught conventionally

The findings in the experimental and control groups were obtained from the differences in average results of personal skills in both groups. The result of interpretation from post-test data analysis of children's personal skills showed that average score in the experimental group was 25.65, while average score in the control group was 21.20. This finding explained that there was an influence of creative movement model on children's personal skills.

After classifying the data into frequency distribution of classified and knowing the average of each group, normality and reliability of the data would be tested as prerequisite for hypothesis testing. The normality test used the Kolmogorof Smirnov and Shapiro Wilk test (Test of Normality) which processed by using IBM SPSS version 24. The result of normality test showed that post test data of both groups are normally distributed. It could see from the significance scores of Kolmogorov-Smirnov and Shapiro-Wilk personal skills in creative movement model (experimental) data which was 0.198 and 0.609 , while group who was not treated with creative movement model (control) was 0.2 and 0.410 . Then the significance number of them was greater than 0.05. As the conclusion, the data of personal skills in experimental group and control group for the statistical was not significant and the null hypothesis was accepted. In other hand, the sample data came from population that had normal distribution.

The result of homogeneity test showed the significance of the children's personal skills was 0.135 . The significance score was greater than 0.05 , then sig. $>\alpha$ had meaning as the variance in each group was homogeneous. Normality and reliability data that already tested before will be tested by hypothesis testing. The result of hypothesis testing which was processed by using IBM SPSS Statistics ver. 24 could be interpreted that Sig. (2-tailed) score was 0.001 . It had meaning the significance score was smaller than $\alpha(0.001<0.05)$. The score of tcount $=3.674$ and ttable $=2.021$ has meaning tcount $>$ ttable. From these two statements, it meant Ho was rejected and Ha was accepted. In addition, there was significant difference in 
the personal skills of children who taught with creative movement model with children who did not get creative movement model on kindergarten students in group B cluster III academic year 2019/2020 in Payangan District.

Hypothesis testing result showed that creative movement model could affect children's personal skills. This result proved a research from Dodge and Colker (Antara, 2016) that found creative movement had greatly contribution to children's social-emotional, cognitive, and physical development. This is also supported by Laban (in Catron, 1999) which stated that moving experience while children were playing made it focused on the aesthetic qualities of motion and bodily skills that lead to personal skills.

Motion is a medium to communicate about something. Creative movement is a place to know self and express emotion freely based on imagination. By knowing self and expressing emotion from their imagination, children are able to develop various potentials within themselves. Based on the findings, it can be concluded that creative motion contributes greatly to all aspects of child development. Creative motion also provides opportunities for children to build their own knowledge, gain experience of bodily skills, develop self-confidence, develop creativity and get to know and express themselves.

The success of practicing personal skills can be stimulated by activities that involve movement. Experience of movement can give children freedom to cultivate their bodies, develop self-confidence, express themselves and develop their creativity. By playing, the experience of moving for children will stimulate body movements, develop self-confidence, and improve abilities when they find physical challenges. Giving moving experience to children can also give children opportunity to be creative, know themselves and express their emotion.

The result of this study is supported by Antara (2018) who found that there were differences in the spatial abilities between children who got creative games with creative motion and children who got creative games by playing roles. As the result, there was influence in using creative games with creative motion and role playing on children's spatial abilities. The spatial ability of children who got creative games with creative motion was higher than the spatial ability of children who got creative games by playing roles.

Hermayanti (2015) also found that creative dancing activity could increase children's confidence which was one indicator of children's personal skills. The results of actions taken from 10 respondents. In pre-cycle, it is found that average confidence of children was $26,25 \%$ and in the cycle I was 55,52\%. Then the score from pre-cycle to first cycle increased by $29.27 \%$. The percentage of next cycle was $87.05 \%$. Then from cycle I to cycle II increased 
by $31.53 \%$. Overall calculation from pre cycle to cycle II increased by $60.80 \%$. This finding explains that creative dancing stimulates children's confidence. Comparing to the present study, the present study investigates wider impact that by providing appropriate creative movement stimulation can stimulate children's confidence, children's self-awareness, and children's initiative. So, from the discussion it could be stated that creative movement model had positive effect on children's personal skills.

Generally, research on personal skills and creative movement is only associated with children's motoric and cognitive development. It indicates there is opportunity to discover new findings in term of children's personal skills. Creative movement model is generally used directly in developing children's physical and motoric. Besides of physical and motoric, creative movement model also impacts on all aspects of child development, including social emotional. While practicing in the field, the simulation of creative movement model can be used to stimulate all aspects of child development (Summer et al., 2008).

Creative movement model provides opportunities for children to master space (visual), coordinate body parts, and know themselves more deeply. Getting to know self has meaning to invite children in learning the members of the body, practicing independent, and stimulating children's initiative in class with creative movement model (Olivia, 2014). Inviting children to move also has impact on children's enthusiasm then the creative movement model for children is not only learning about moving with motoric skill but also training their personal skills.

The importance of personal skills stimulation for children to prepare and equip children in facing various learning levels of further education. With this finding, parents and especially educators expected to be willing to develop various activities that can stimulate children's personal skills more optimally and sustainably. Thus, the benchmarks of children's achievement not only through academic and motor activities, but also prioritize to giving stimulation for children's personal skills.

\section{Conclusion}

Motion is a medium to communicate about something. Creative movement is a place to know and express children's self and emotion freely based on their imagination. Creative movement model provides opportunities for children to master space (visual), coordinate body parts, and know themselves more deeply. Getting to know self has meaning to invite children in learning the members of the body, practicing independent, and stimulating 
children's initiative in class with creative movement model. Inviting children to move also has impact on children's enthusiasm then the creative movement model for children is not only learning about moving with motoric skill but also training their personal skills.

The findings on experimental group and control group showed both groups had same ability or equivalent and it was changing after the experimental class got treatment. This change could be seen from the difference of grades and class averages between the experimental group and the control group which was quite significant. The average score of personal skills in the control class was belong to moderate category while in the experimental class was good category. Based on this study it can be concluded that there was a significant influence on the creative movement model with the students' personal skills of Group B Cluster III Kindergarten school year 2019/2020 in Payangan District.

One aspect that is very important and must be stimulated properly is social emotional aspect. Most people believe that social emotional aspect is not the priority to be developed; instead, they more emphasize on the stimulation to cognitive and motoric aspects. Therefore, teachers need to understand that all developmental aspects are equally important and needs to be developed to children. Educators are expected to be willing to develop various activities that can stimulate children's personal skills more optimally and sustainably. Thus, the benchmarks of children's achievement are not limited to developing their cognitive aspects, but also social emotional aspect.

\section{References}

Antara, P.A. 2015. Analisis Gerak Kreatif Dan Bakat Seni Dalam Menstimulasi Kemampuan Spasial Anak (Studi Pada Kelompok B Taman Kanak-Kanak Di Kecamatan Blahbatuh, Kabupaten Gianyar, Propinsi Bali). Hal 45-58

Antara, P. A. 2018. Stimulasi Metode Permainan Kreatif Berdesain Creative Movement Dalam Menumbuhkan Kemampuan Spasial Anak Dengan Mempertimbangkan Budi Pekerti. 12 (November), 301-310.

Catron, E. Carol \& Jan Allen. 1999. Early Childhood Curriculum A Creative-Play Model Second Edition. $\mathrm{Nj}$ : Merril Prentice Hall.

Dantes, N. 2012. Analisis Dan Desain Eksperimen. Singaraja: Program Pasca Sarjana Undiksha.

Dow, C. B. 2010. The Power of Creative Dance. In Performing Arts: Music,Dance, and Theater in the Early Years (Issue 2 March, pp. 31-33).

Gallahue, David L. And John C. Ozmun. 1998. Understanding Motor Development. Usa: The Mcgraw-Hill Companies. 
Hawkins, A. M. 2003. Bergerak Menurut Kata Hati. Metode Baru Dalam Menciptakan Tari, Diterjemahkan Oleh I Wayan Dibia, Jakarta: Ford Foaundation Dan Masyarakat Seni Indonesia.

Hermayanti, T.2015. Peningkatan Kepercayaan Diri Melalui Tari Kreatif. 389-400.

Hidayat, A., \& Darma, U. B. (2017). Peningkatan aktivitas gerak lokomotor, nonlokomotor dan manipulatif menggunakan model permainan pada siswa sekolah dasar. Pendidikan Jasmani Dan Olahraga, 2(September), 21-29.

Hurlock, E. B. 1978. Perkembangan Anak, Jilid 2. Alih Bahasa Meitasari Tjandrasa. Jakarta: Erlangga

Kostelnik, M.J., Soderman, A.K., Dan Whiren, A.P. 1999. Developmentally Appropriate Curricullum, Best Practices in Early Childhood Education. New Jersey: Prentice Hall.

Kusumaastuti, Eny. 2014. Penerapan Model Pembelajaran Seni Tari Terpadu Pada Anak Sekolah Dasar. Mimbar Sekolah Dasar. Volume 1 Nomor 1. 44-56

Laban Rudolf. 1988. Modern Education Dance. London: Mac Donald and Evans.

Lazarus, R.S.1991. Emotion in Adaptation. New York: Oxford University Press.

Mashar, Riana. 2011. Emosi Anak Usia Dini Dan Strategi Pengembangannya. Jakarta: Kencana.

Nugraha, Lesmana dkk. 2017. Penerapan Model Pendidikan Gerak Dalam Mengembangkan Pola Gerak Dasar Manipulatif Melalui Kerangka Analisis Gerak (Movement Anvlysis Framework) Vol. 2, No. 2. Hal 22-56

Olivia, G. 2014. Education to Theatricality : Creative Movement as a Training Model. Global Journal Od Human Social Science : G Linguistics and Education, 14(9), 1-18.

Papalia, D.E., Olds, S.W., and Feldman, R.D. 2002. Child's World, Infancy Through Adolences. Ninth Edition. Boston: Mcgraw-Hill.

Skoning, S. N. (2008). Movement and Dance in the Inclusive Classroom Movement and Dance in the Inclusive Classroom. TEACHING Exceptional Children Plus, 4(6).

Smith, J. (2003). Dance Composition. A Practical Guid For Teacher. Surrey: Unwin Brothers Ltd.

Sriningsih, N. (2010). Program Pengembangan Kecakapa Pribadi (Personal Skills) di TK. Cakrawala Pendidikan, 2(2), 1-10.

Sugiyono. 2009. Metode Penelitian Kuantitatif Dan Kualitatif Dan $R$ \& D. Bandung: Alfabeta.

Summers, J., Larkin, D., \& Dewey, D. 2008. Activities of daily living in children with developmental coordination disorder: Dressing, personal hygiene, and eating skills. Human Movement Science, 27(1), 215-229. https://doi.org/10.1016/j.humov .2008 .02 .002

Yusria. 2016. Peningkatan Kecakapan Personal Melalui Pembelajaran Kontekstual. Jurnal Pendidikan Anak Usia Dini, 10(2), 327-348. https://doi.org/https://doi.org/10.21009 /JPUD.102 